\title{
Er retningslinjene for oppfølging av AD/HD gode nok?
}

\author{
I de nye faglige retningslinjene for AD/HD hos barn gis det anbefalinger om behandling og oppfølging med \\ sentralstimulerende midler. Vi vil drøfte anbefalingene opp mot viktigheten av god etterlevelse for en bedre \\ langtidsprognose.
}

$\mathrm{AD} / \mathrm{HD}$ (attention deficit/hyperactivity disorder) er en av de vanligste barnepsykiatriske tilstandene og finnes hos $3-5 \%$ i barnealder (1). Etter utredning og oppstart med sentralstimulerende midler i spesialisthelsetjenesten overtar fastlegen ansvaret for medisineringen. Behandling med sentralstimulerende midler har betydning for langtidsprognosen $(2,3)$. Etterlevelse av behandlingen krever tett oppfølging.

Tilstanden er kronisk og gir funksjonssvikt på flere livsområder: skole, sosialt, familie. I de faglige retningslinjene fra 2014 anbefales et helhetlig tilbud med foreldreveiledning, tilrettelegging i skolen og utprøvning av sentralstimulerende midler (1).

Utredning for og oppstart av behandling med sentralstimulerende midler foretas av spesialisthelsetjenesten, mens fastlegene har en sentral rolle i oppfølging av medisineringen etter utskrivning. I retningslinjene anbefales det at oppfølgende lege foretar minimum halvårlige somatiske kontroller og vurderer medikamentets effekt og bivirkninger for eventuelt å justere doseringen eller skifte medikament (1).

\section{Tett oppfølging viktig}

Prognosen for hvordan barn med AD/HD vil utvikle seg er varierende. Den er avhengig av flere faktorer, blant annet behandling med sentralstimulerende midler $(2,4,5)$. Undersøkelser fra utlandet viser ikke entydig at bruk av sentralstimulerende midler er gunstig for prognosen (6), mens undersøkelser fra Norge viser at de er det $(2,4)$.

En undersøkelse fra 2012 viste at $30 \%$ av barn med AD/HD behandlet ved Statens senter for barne- og ungdomspsykiatri i årene 1968-88 hadde uføretrygd som voksne (3). Disse hadde en høy grad av funksjonssvikt og samsykelighet. I en annen norsk undersøkelse var $24 \%$ av de voksne med AD/HD $\mathrm{i}$ arbeid, mot $79 \%$ i kontrollgruppen (2). Den viktigste prediktoren for AD/HD-pasientenes arbeidsevne $\mathrm{i}$ voksen alder var behandling med sentralstimulerende midler som barn.

Bruk av sentralstimulerende midler kun i barneårene har ikke sikker effekt på langtidsprognosen. Etterlevelse i ungdomstiden er viktig (6). Studier viser at mange ungdommer slutter med sentralstimulerende midler, til tross for at mange rapporterer om god effekt og lite bivirkninger (7-10). Mindre kontroll fra foreldre og økende selvstendighet ble ansett som mulige årsaksforklaringer.
Doseringen av sentralstimulerende midler bør være dynamisk, og det bør tas hensyn til individuelle faktorer (11). Effektevaluering, dosejustering, seponeringsforsøk og kartlegging av samsykelighet er faktorer som bør følges nøye for at man skal lykkes med behandlingen $(8,9,11)$.

\section{Hva vet vi om oppfølgingen?}

Det foreligger ingen norske undersøkelser om langtidsetterlevelse av bruk av sentralstimulerende midler hos barn med AD/HD. Fra egen praksis som fastlege i over ti år, med ansvar for oppfølging av disse pasien-

\section{«Det finnes gode grunner til at også opp- følging av behandling med sentralstimule-} rende midler skal

\section{være spesialisthelse- tjenestens ansvar»}

tene, har førsteforfatter sett at det kan være mangelfull etterlevelse. Pasientene kan ha gått $\mathrm{i}$ flere måneder uten medisiner uten at fastlegen har vært klar over det. Ofte er det ikke noen systematisk oppfølging med innkalling til timeavtale. Dessuten har hver enkelt fastlege få AD/HD-pasienter og varierende kompetanse på området. Dette er erfaringer som deles av andre fastleger førsteforfatter har hatt faglige diskusjonsmøter med.

Vi kjenner ikke det eksakte antall barn og unge som følges opp av fastlege for $\mathrm{AD} / \mathrm{HD}$-medisinering i Norge, men det er ikke urimelig å anta at det dreier seg om et betydelig antall. I 2014 hadde 6235 barn og unge i BUP en AD/HD-diagnose, ifølge Norsk pasientregister (12). Tall fra vår poliklinikk, BUP Nedre Romerike, viser at ca. $60 \%$ av pasientene brukte medisiner for $\mathrm{AD} / \mathrm{HD}$ (hovedsakelig sentralstimulerende midler) ved utskrivning.

\section{Spesialister bør ha ansvaret}

De nye retningslinjene gir for mye rom for skjønn. Fastlegene har ofte ikke noe eget system for innkalling og oppfølging hvis pasientene ikke møter til timer de selv har tatt initiativet til. Det vil kunne være behov for tydeligere retningslinjer for hvordan fastlegene spesifikt skal følge opp mennesker med $\mathrm{AD} / \mathrm{HD}$. I familier der et barn har $\mathrm{AD} / \mathrm{HD}$, kan både foreldrene og barnet/ ungdommen slite med organisering og vil kunne trenge hjelp til struktur når det gjelder oppfølging hos fastlege (13). Tiltak fra fastlegene, som hyppigere kontroller, innkallingsstruktur og dynamisk dosejustering, kan gi bedre etterlevelse (14).

Det finnes gode grunner til at også oppfølging av behandling med sentralstimulerende midler skal være spesialisthelsetjenestens ansvar (15). Hver enkelt fastlege har få pasienter med $\mathrm{AD} / \mathrm{HD}$ og får dermed ikke muligheten til å opparbeide seg erfaring med individuell og dynamisk medisinering etter hvert som barnet utvikler seg. Spesialisthelsetjenesten har større erfaringsgrunnlag og bedre muligheter for å lage struktur for pasientene - og dermed sikre etterlevelsen. Dessuten har man tilgang til fagpersoner som kan gi det helhetlige tilbudet som anbefales i retningslinjene fra Helsedirektoratet (1).

Vår viktigste innvending mot de nye retningslinjene er at man gir føringer for en praksis uten å vite om dette gir god nok etterlevelse. Det dreier seg om et stort antall pasienter der all tilgjengelig kunnskap tilsier at tett oppfølging er viktig for prognosen. Per i dag vet vi for lite om oppfølgingen av bruk av sentralstimulerende midler ved $A D / H D$ i Norge - hva slags oppfølging pasientene får, langtidsetterlevelsen $\mathrm{og}$ hvordan dette påvirker langtidsprognosen. Behandlingen som gis, bør på sikt føre til at pasientene får mindre funksjonssvikt på viktige områder i livet og bedre langtidsprognose.

\section{Hanne Cecilie Kaspersen \\ han-ck@hotmail.com} Berit Hjelde Hansen

Hanne Cecilie Kaspersen (f. 1971) er spesialist i allmennmedisin og lege i spesialisering ved BUP Nedre Romerike, Akershus universitetssykehus.

Forfatter har fylt ut ICMJE-skjemaet og oppgir ingen interessekonflikter. 
Berit Hjelde Hansen (f. 1957) er spesialist i barne- og ungdomspsykiatri, ph.d. og overlege ved BUP Nedre Romerike, Akershus universitetssykehus.

Forfatter har fylt ut ICMJE-skjemaet og oppgir ingen interessekonflikter.

\section{Litteratur}

1. ADHD/Hyperkinetisk forstyrrelse. Nasjonal faglig retningslinje for utredning, behandling og oppfølging. IS 2062. Oslo: Helsedirektoratet, 2014

2. Halmøy A, Fasmer OB, Gillberg C et al. Occupatio nal outcome in adult ADHD: impact of symptom profile, comorbid psychiatric problems, and treatment: a cross-sectional study of 414 clinically diagnosed adult ADHD patients. J Atten Disord 2009: 13: 175-87

3. Mordre M, Grøholt B, Sandstad B et al. The impact of ADHD symptoms and global impairment in childhood on working disability in mid-adulthood: a 28-year follow-up study using official disability pension records in a high-risk in-patient population. BMC Psychiatry 2012; 12: 174

4. Fredriksen M, Peleikis DE. Long-Term Pharmacotherapy of Adults With Attention Deficit
Hyperactivity Disorder: A Literature Review and Clinical Study. Basic Clin Pharmacol Toxicol 2015 n/a. . [Epub ahead of print].

5. Biederman J, Faraone SV, Spencer TJ et al. Functional impairments in adults with self-reports of diagnosed ADHD: A controlled study of 1001 adults in the community. J Clin Psychiatry 2006; 67: $524-40$.

6. Molina BS, Hinshaw SP, Swanson JM et al. The MTA at 8 years: prospective follow-up of children treated for combined-type ADHD in a multisite study. J Am Acad Child Adolesc Psychiatry 2009. 48: 484-500.

7. Swanson J, Arnold LE, Kraemer $\mathrm{H}$ et al. Evidence interpretation, and qualification from multiple reports of long-term outcomes in the Multimodal Treatment Study of children with ADHD (MTA): Part II: supporting details. J Atten Disord 2008; 12: $15-43$.

8. Charach A, Gajaria A. Improving psychostimulant adherence in children with ADHD. Expert Rev Neurother 2008; 8: 1563-71.

9. Charach A, Fernandez R. Enhancing ADHD medication adherence: challenges and opportunities. Curr Psychiatry Rep 2013; 15: 371.

10. McCarthy S, Asherson P, Coghill D et al. Attentiondeficit hyperactivity disorder: treatment discontinuation in adolescents and young adults. Br J Psychiatry 2009; 194: 273-7.
11. Powell SG, Thomsen PH, Frydenberg M et al. Long-term treatment of ADHD with stimulants: a large observational study of real-life patients. J Atten Disord 2011; 15: 439-51.

12. Norsk pasientregister. Aktivitetsdata for psykisk helsevern for barn og unge. IS 2289. Oslo: Helsedirektoratet, 2014.

13. Langberg JM, Dvorsky MR, Evans SW. What specific facets of executive function are associated with academic functioning in youth with attention-deficit/hyperactivity disorder? J Abnorm Child Psychol 2013: 41: 1145-59.

14. Gajria K, Lu M, Sikirica V et al. Adherence, persistence, and medication discontinuation in patients with attention-deficit/hyperactivity disorder a systematic literature review. Neuropsychiatr Dis Treat 2014: 10: 1543-69.

15. NICE Quality Standard for AD/HD. London: The National Institute for Health and Clinical Excellence, 2013.

Mottatt 11.10. 2015, første revisjon innsendt 22.11. 2015, godkjent 23.11. 2015. Redaktør: Inge Rasmus Groote.

Publisert først på nett 